\title{
From Skills to Practice: How Does Information Literacy Happen?*
}

Annemaree Lloyd**

\begin{tabular}{|l|}
$\begin{array}{ll}\text { 1. Introduction } \\
\text { 2. Three views of information literacy }\end{array}$ \\
$\begin{array}{ll}\text { 3. Skills-based view and instructional } & \text { does it happen? } \\
\text { practice } & \text { 10. Reframing information literacy } \\
\text { 4. Information literacy as experiencing } & \text { 11. A landscape approach to information } \\
\text { information } & \text { literacy: Landscapes and modalities } \\
\text { 5. Information literacy as a socially } & \text { 12. Social modality } \\
\text { enacted practice } & \text { 13. Corporeal modality } \\
\text { 6. A theoretical framework for } & \text { 14. From skills to practice } \\
\text { Information literacy } & \text { 15. What is an information literate } \\
\text { 7. Information literacy as practice } & \text { person? } \\
\text { 8. How is information literacy practice } & \text { 16. Implications for researchers and } \\
\text { constituted? } & \text { library practitioners }\end{array}$ \\
\hline
\end{tabular}

\section{ABSTRACT}

The use of a practice perspective in the analysis of information literacy represents a shift in attention towards the enactment of information literacy as a social practice, and away from the information skills approach that has dominated information literacy research and education. The sociocultural perspective that underpins a practice-oriented approach highlights the role of practice and co-participation of the community in shaping the production, reproduction and circulation of knowledge, including knowledge about the appropriateness of information skills in relation to the context in which the skills are practised. This emerging view contrasts with the conventional approach to information literacy that has focused on the information skills of individuals as something that can be learned and transferred independently of context. This paper explores two questions: what is information literacy and, how does it happen? It then goes on to identify the implications of this approach for librarians and researchers.

Keywords: Information Literacy, Information Landscape, Knowledge and Information, Information Modalities

* The paper was originally presented at the International Conference commemorating the 40th Anniversary of the Korean Society for Library and Information Science held in Seoul, Korea on October 8, 2010.

** Lecturer, School of Information Studies, Charles Sturt University, Wagga Wagga, NSW, Australia (anlloyd@csu.edu.au)

논문접수일자: 2010년 8월 31일최초심사일자: 2010년 9월 16일 게재확정일자: 2011년 5월 23일 한국문헌정보학회지, 45(2): 41-60, 2011. [DOI:10.4275/KSLIS.2011.45.2.041] 


\section{Introduction}

Our ability to become information literate is brought about through our engagement with the specific ways of knowing an information landscape through our knowledge of the range of information modalities, that are sanctioned as the 'collective possession' of a particular site (Schatzki, 2001, p.6); and, through the activities that enable us to access, disseminate and circulate information. In this presentation, I wish to elaborate on an emerging view of information literacy (IL) as a socially enacted practice, one that is shaped in contextually specific ways.

This emerging approach to understanding information literacy differs from current views where information literacy is understood as a skill or an experience with information. The approach does not focus on the individual but seeks to understand how information literacy happens as collective practice, and how the activities that enable information literacy to be enacted are legitimized. From a practice perspective, information literacy is viewed through the cultural-discursive, material and historical discourses that surround the collective acceptance, use, production, reproduction and circulation of information in various forms.

A continuing issue in the debate about information literacy is the lack of a theoretical framework which can be used to explain the complex socio-cultural arrangements that inform our understanding of what information literacy is and how it happens in the various settings that underpin the information literacy research agenda (e.g. schools, academic, vocational settings and the workplace). This has led researchers such as Bruce, Edwards and Lupton (2007, p.37) to suggest that 'information literacy is not a theory of learning, but rather that people's approaches to information literacy and information literacy education are informed by views of teaching, learning and IL which they adopt either implicitly or explicitly in different contexts'. Similarly, the position from which information literacy research has been undertaken (e.g. from a library-based perspective) has led researchers such as Boon, Johnston \& Webber, (2007, p.205), to suggest that it is still librarians' conceptions and experiences that have dominated the literature and their frameworks and models for information that have been the most visible'.

This paper is framed through the theoretical work of Schatzki $(2001,2002)$ who posits that social life is constituted through a nexus of practices and material arrangements that hang together. It also draws from the practice-oriented research of Gherardi (2009), who argues that knowing is 'a practical and situated activity' (Gheradi, 2009, p.124). This provides the ontological and epistemological framework that informs my own understanding of what information literacy is and how it happens. 
When research into information literacy is approached from a practice perspective the emphasis in placed on the sociality of the 'practice', as constituted through shared understandings of how information and its dissemination and circulation are agreed upon. Understanding how information literacy as an information practice is shaped and what conditions leads to this shaping, enables us analyse how the skills and competencies, the attention of much information literacy research, are bought into focus. Thus knowing (about the information landscape) and doing (practising information literacy) are unified. The practice approach has implications for information literacy pedagogy because is encourages educators in preparatory settings such as schools, academic and vocational training centres to focus on the social conditions that shape and inform collective learning, and to draw from these in the preparation of tomorrow's life long learners.

This view stands in contrast to the traditional skills based discourse that surrounds information literacy in the education sector. While the skills based approach may be appropriate for schools and for the work-related learning that dominates the higher education sector and training organizations, the skills-based approach to information literacy does not prepare learners to engage with the everyday learning that is involved in the normal conduct of work or everyday life. The skills based approach results in tunnel vision for researchers, who by focusing on skills tend to divorce the process from the conditions that influence the emergence of the practice as unique to the setting. It thus divorces the information literacy process from the critical thinking skills that are specific and unique to each setting.

\section{Three views of information literacy}

The 'history' of information literacy is now over 40 years old and has been well documented in the library and information science and teacher librarian literature. It should be remembered, however, that it is from the workplace that the term information literacy first emerged. Zurkowski (1974) expressed his concerns that the exponential growth of information and the increasing complexity of information dissemination, access, storage and retrieval that had resulted from the introduction of computers to the workplace would affect workers performance in the service industry. Zurkowski, linked information literacy with economic and organisational goals, and the ability of workers to develop information related skills that would enable them to solve problems related to computer-based workplace tasks. He suggested that: 
'people trained in the application of sources to their work can be called information literate. They have learned techniques and skills for utilizing a wide range of information tools as well as a primary sources in moulding information solutions to their problems'.

Apart from Zurkoski's initial concerns about workers readiness to deal with the new information age, the idea of information literacy did not really take hold in the workplace at this time. Even today, while there has been some progress in the white-collar sector, there has been little progress in other vocational sectors, particularly in areas where there is greater reliance on embodied and social information as important sources for informal learning.

It was in the education sector and among librarians and teacher librarians in particular that the currency of information literacy as a skills-based practice was understood and embraced. In this sector information literacy is view not only as a subject of pedagogical interest, but also as a tool for advocacy of clients and in support of librarians as information providers and educators.

In recent times other views of information literacy have also emerged which have challenged the skills-based view and deepened our understanding of the phenomenon and its relationship to learning in both formal and informal settings. The role of information literacy as a catalyst that enables learning has been driven by the phenomenographic work of Bruce and her colleagues. More recently researchers (Limberg \& Sundin, 2006; Lloyd, 2006b) have employed sociocultural theoretical perspectives that focus on highlighting the various ways in which information literacy as a social practice is spoken about, acted upon and inextricably tied to the activity of the setting where information and knowledge are produced. These three views will be briefly explored.

\section{Skills-based view and instructional practice}

In 1980s and early1990s the conceptualization of information literacy reflected the reference skills of librarians and the research process, and was connected to the emerging technologies being introduced within the school and higher education sector. The research of Doyle (1992) strongly reflected this instrumental approach and provided a definition of information literacy that is still adopted and adapted in various forms today. In the education sector information literacy is defined as: 
Doyle also described a series of attributes that an information literate person should possess. These are:

- recognition of an information need and for the need for complete information;

- ability to formulate questions;

- recognition of potential sources of information;

- development of successful search strategies;

- ability to evaluate, organize and apply information;

- ability to integrate information into bodies of knowledge, and,

- the ability to think critically and solve problems using information.

Many librarians in education have taken up Doyle's work and her definitions and attributes are reflected in the standards for information literacy found in Australia, the United States, and the United Kingdom.

Based on Doyle's work, the American Library Association (ALA) definition which has been adapted by Council of Australian University Librarians (CAUL) in Australia characterizes an information literate person as one who is able to consciously identify the need for information after which they must have the ability to execute a range of skills and demonstrate a range of attributes (Bundy, 2004). These skills include the ability to effectively use the required information to make judgements about information against the setting from which the need has arisen. Numerous attempts have made to measure information literacy as set out in the standards. These attempts have met with various successes and indicators for information literacy have been reported in the research literature (Catts, 2005; Catts \& Lau, 2008). The attempts to measure information literacy have also produced tensions among information literacy scholars, where the approach is seen to be embedded in behaviourist traditions of teaching and assessment, an antithesis to constructivist focused enquiry based learning models (Catts \& Lau, 2008).

\section{Information literacy as experiencing information}

In 1997, Christine Bruce produced the Seven Faces of Information Literacy and through this phenomenographic work connected information literacy to the experience of learning, by identifying the variation of experiences that students have with information. Focusing on the intellectual capabilities of the student, Bruce suggested that the 'ability to locate, manage and use information 
has been labelled 'information literacy' Today information literacy is recognized as making an important contribution to decision making, problem solving, independent learning, continuing professional development and research'. For Bruce (2000, p.97) information literacy is an 'appreciation of the complex ways of interacting with information. It is a way of thinking and reasoning about aspects of subject matter. Bruce's phenomenographic approach to information literacy has been taken up by a number of researchers, including Limberg (2000), Lupton, (2004), and Edwards (2006).

\section{Information literacy as a socially enacted practice}

The sociocultural approach that has recently emerged draws from a range of theories that emphasise shared ways of interacting and communicating. This approach to information literacy emphasises the situatedness of information and its constructed outcome - knowledge, as socially bound phenomenon. It focuses on the social, corporeal and epistemic relationships between people, in co-participation, and in relation to the signs, symbols and artefacts that constitute the material conditions of the practice and which provide affordances within the information landscape (Lloyd, 2005). From this perspective the approach to information literacy is not focused on the individual, or on information literacy as a singular literacy. Rather the approach advocates that information literacy is a complex array of information related activities that are shaped into practice, reflecting the cultural and historical conditions from which they take form (Talja \& Lloyd, 2010). Within the sociocultural framework, practice theory has begun to emerge as a theoretical framing for information literacy.

\section{A theoretical framework for Information literacy}

The practice turn that is emerging in a number of fields including library and information science highlights a shift in theorizing about social phenomenon (Palmer \& Craigin, 2008; Savolainen, 2007; Schatzki, 2001; Scheeres, Solmon, Boud \& Rooney, 2010). In library and information science it also heralds a more interdisciplinary approach with researchers drawing from organizational, educational, workplace learning theory.

Researchers adopting a practice-oriented approach have turned their focus towards highlighting 
the conception that human activity is constituted through fields of practice (the total nexus of all human practices within a setting) or as Schatzki (2002) suggests the site of the social through which phenomena such as 'knowledge, meaning, science, power, language and social institutions' (Schatzki, 2001, p.2) can be located and understood through accounts of practice and practising. This approach sees information literacy as a practice that is co-constructed and co-located (Lloyd, 2005), emerging as a 'temporally unfolding and spatially dispersed nexus of doings and sayings' (Schatzki, 1996, p.89). In forming a practice, doings and sayings are linked in particular ways. Three areas of linkage are identified by Schatzki (1996, p.86) as: understandings; explicit rules, principles and instructions; and, through teleoaffective structures that embrace 'ends, projects, tasks, purposes, beliefs, emotions and moods' (1996, p.89). For those who are interested in how information literacy manifests itself within a setting, the use of a practice-oriented approach aims at developing an account of how information literacy as a practice is constituted and enacted in relation to setting and to other practices within the setting. This leads us to explore the notion of what constitutes a practice, more specifically, what constitutes information literacy as an information practice.

\section{Information literacy as practice}

A practice is a nexus of organized actions and activities that hang together and overlap to form a mesh of practice (Schatzki, 2006). According to Schatzki (2006) a practice consists of a structure that enables participants to understand the 'how to' of practice e.g. the rules, goals, ends and more general understanding. Practices also consist of action i.e. 'the carrying out of a practice in specific time space contexts' (Scheeres, et al., 2010, p.18). From a practice perspective, practices are not seen as the property of individuals, but are instead the property of the social site (Lloyd, 2010a; Schatzki, 2002). Practices can be divided into two types, integrative and dispersed practices. Integrative practices are complex higher order practices, which encompass dispersed practices and are constitutive of particular domains of social life (Schatzki, 1996, p.98). Examples of integrative practices may include education, work, or library management practice. Dispersed practices flow within all areas of social life and they appear in higher order practices which 'centre around a single type of action' (p.88) such as describing, ordering, questioning, reporting, and examining (Schatzki 2002,p.88; Lloyd 2010). Information literacy is a dispersed practice that hangs together as a bundle of information focused activities that act as the catalyst for learning 
the larger integrative practices (Lloyd, 2010, p.249). How information literacy practice emerges, will be shaped by the social, historical, political and economic features that are prefigured within the site (Lloyd, 2010, p.249). Therefore in educational contexts, where objectivist discourses about what constitutes knowledge are reflected in regimes of instrumental competence, the focus of information literacy will be on the development and measurement of skills.

\section{How is information literacy practice constituted?}

As the property of the social site, practices are constituted in three ways. Firstly, an understanding of how to do things (practical understandings), such as explaining or describing or questioning. Secondly, rules or formulations that prescribe require or instruct. Thirdly, teleoaffective features which structure emotions that are acceptable or prescribed in practice (Schatzki, 2006). The analysis of practice can't be reduced to its cognitive features, but needs to provide an account of how the practice is also constructed corporeally and socially and consider how these features are interwoven and meshed together within a social site. Schatzki (2001) argues that practices are 'embodied materially mediated arrays of human activity, centrally organized around shared practical understanding' (p.2). This suggest that as a practice information literacy is not confined to objective forms of information or knowledge, but must also account for corporeal information i.e. information drawn from the performing body, in addition, to nuanced, tacit and contingent forms of information that are not able to be expressed in textual form, but are critical to engaging with the information landscape.

As a practice, information literacy emerges within a site through the shared nuanced and embodied understandings about context; through the formations that prescribe, require or instruct; and, through the teleoaffective features specific to the site, through which beliefs and values act to influence the collective space of the practice. The formation of information skills or competency is thus prefigured by the social setting in which a person enters and operates and reflects the 'sayings and doings of the social site in relation to discourses that characterize the site. This type of information is critical in that it enables people to develop and engage in co participatory practice, to develop expertise. Engaging with corporeal and social information enables people to learn how to go on. 


\section{What is information literacy and how does it happen?}

The idea that information literacy can be defined as a set of generic and transferrable information skills and that its outcomes can described in relation to a set of attributes does not tell us under what circumstances and in what conditions information literacy happens. Nor does it tell us how these skills are developed.

As a result of my research in the workplace ( Lloyd, 2003; 2006a, 2007; 2009), I understand information literacy to be formed through a complex array of activities that are influenced according to the ontology and epistemology that structure a setting. This structure provides an architecture that prefigures practices (including the practice of information literacy) within a setting 'enabling and constraining them in particular kinds of sayings, doings and relatings among people $\cdots$ ' (Kemmis \& Grootenboer, 2008, p.57). As a practice, information literacy is shaped according to the cultural-discursive, material-economic dimensions, giving substance and form to what is considered to be information, what is sanctioned as knowledge and the methods and techniques that legitimize action and activity around the production, reproduction, circulation and dissemination of information. As all contexts are uniquely shaped we must therefore consider that information literacy happens in different ways relative to the specific setting. Consequently, the practice of information literacy for fire fighters (Lloyd, 2006) engaged in the performance of work is one where information is valued and derived from experiential, embodied and social sources. This will differ from more epistemic contexts such as schools and higher education where objective information and knowledge is sanctioned and instrumental ways of knowing are legitimized.

As a practice, information literacy produces a way of knowing about the information landscape within which a person is situated. By this I mean that as generative source of knowledge, the practice of information literacy not only enables knowing about content, but also knowing about:

- how information is enabled, afforded, nuanced, or contested within a setting;

- the modalities of information that are considered credible and authoritative to the setting; and,

- how to employ the appropriate information skills, which enable an understanding of

- how to 'go on' in the performance of learning or working.

The focus of this approach is therefore not only on objective information and instrumental ways of knowing. It also attends to intersubjective and embodied information that is brought about by people in co-participation, allowing them to come to a mutual understanding about 
what information and ways of knowing are valued and sanctioned within the landscape, through our engagement with the signs, symbol, artefacts and other people who are engaged within the specific setting.

\section{Reframing information literacy}

Traditional approaches to information literacy emphasise developing learners' information skills in relation to specific types of tools (e.g. print and digital literacy). The approach advocated in this paper, places emphasis on the conditions that enable information to be agreed upon by people in co-participation, because it is within this process that ways of access and ways of knowing are also agreed upon. Information literacy is not just concerned with access to textual information, it is also concerned with learning to do (acquiring skills and competence) learning to be (engaging with information to develop professional identity) and learning to live together (engaging with information that enables people to work and learn together (Delor, 1996, p.37).

Information literacy research should therefore focus on developing critical understandings of how information is valued within a social site and how the 'sayings, and doings' (Schatzki, 2002) facilitate a persons development of information practice and engagement with information, through a range of activities and subsequently enables a way of knowing about the information landscape. Knowing does not simply reflect the epistemic cultures that articulate the systems through which we practise; knowing reflects our ability to make meaning from social and material relations. This approach to understanding information literacy takes into account explorations of the sociocultural contexts through which people participate and considers what information is valued, the modalities of information that are legitimised and the activities that are employed in order for people to engage with information.

Therefore it is through the intersubjective space that information literacy is constituted. In this space people come to mutual understandings about the meanings of actions, tools, symbols and language. They come to this understanding by agreeing on what types of information are legitimate and valued. The view of Bateson (1972, p.457) that information is 'any difference that makes a difference' is entirely appropriate because it suggests that if information is to mean something, then it must be situated and made intelligible through the contextual lens of social life. For knowledge to be constructed information must be agreed upon and be understood to make a difference. This alludes to the notion that knowledge is not arbitrary and therefore outside a social field, 
but is situated and spun inside a social site by practices- including information literacy practices that reveal the nature of the relationship between the cultural and the material (Lloyd, 2010a).

The idea that 'knowledge is always a view from somewhere' has been presented by Barad (1996, p.180). This author suggests that the representation of knowledge within a social setting, reflects the intersubjective meanings and local knowledge claims of specific communities and its shared understandings about the nature of knowledge, that has been prefigured overed time by socio-cultural, material and historical arrangements within a site. This is relevant to the emerging construct of information literacy as practice and highlights the fluid nature of information literacy practice as being dispersed within other higher order practices such as learning to be a good workers, teachers, dancer or even football players (Lloyd, 2010a, p.251).

To summarize, the practice-oriented approach to information literacy highlights that:

- information and knowledge are socially produced through practices that reflect the social nature of a site;

- becoming information literate is a collective process influenced by ways of knowing that are collectively sanctioned and agreed upon; and,

- knowing an information landscape requires an understanding of the organization of the site, through a range of information modalities.

\section{A landscape approach to information literacy: Landscapes and modalities}

I use this analogy of landscape to try to convey some of the complexities that we face when we try to understand information literacy as a socio-cultural practice. While the idea of landscape summons a spatial, visible expanse of natural or man made terrain, in the present work, the landscapes that people encounter and interact are considered to be socially constructed and therefore accessible through co-location, and co-participation.

An information landscape refers to the intersubjective space that is created when people come together in practice or sets of practice: where information is shared, enabled and/or constrained. Though our engagement with this type of landscape that we negotiate our realities- through our discourse we come to agreement and where we commit to action and to perform in agreed ways (Lloyd, 2010b).

Information landscapes are structured through a web of related practices that give the landscape 
a shape and character. In a school based setting, the meta-practice of education will have nested within it a number of other practices, such as teaching, learning, administrative practices. In turn, these practices will also consist of other practices and so on. This structuring enables certain types of information while it constrains others. Though co-location and co-participation, members engage with information and learn about social formation and arrangements, learn about its patterns and cycle, and about the paths nodes and edges that form the topography of the social site. It also allows them to learn about what information is sanctioned and legitimised. Consequently in educational landscapes, information literacy as practice will differ from a workplace landscape because the structuring of the practice will be influenced by the sayings doing and relatings that reflect the workplace discourse.

All information landscapes are socially produced and maintained through membership. When we first engage with the landscape (e.g. through our occupation or professional practice, education, or other circumstances such as a health issue) we have to learn about it, about the powerful forces that shape it, we have to map its resources, to interpret its language and nuances and we have to learn about its social, historical, political and economic trajectories and how these dimensions shape the practices within it: this includes information practice (Lloyd, 2010b).

When we first engage in an information landscape we do so as novices and others recognize us in this way and we need some kind of map in order to locate ourselves. This is where preparatory training helps us. Over time as we become more engaged we develop information expertise and we move from being a newcomer to becoming an old timer. As we become more experienced member of the group we are better equipped to be able to look outside our landscape to seek new information that will increase our knowledge. We create distributed networks and we draw from these networks to enhance and deepen our own information practices and the practices of others. To engage with our information landscapes we need to:

- identify the modalities of information which people engage with and which are sanctioned;

- engage in a range of site appropriate activities which connect us to these modalities; and

- employ appropriate information skills.

Three broad modalities emerge from my own research, through which individuals must connect in order to learn about the practices of their landscapes. Briefly these are:

- Epistemic - which act as location for 'know-why' information. This type of information is codified into written rules, regulations, and can be clearly articulated against a set of sanctioned criteria. This type of information is tightly bound to institutional 
forms of knowledge and is used to enact an identity that is recognizable to the institution. Distinguished by the use of the written word (print or digital form) information is discursively produced and its use promoted by specific communities that represent particular ideological positions, values, beliefs and attitudes. Users experience knowledge as a universal, generalizable and abstract; truth is objective, discoverable, reproducible and is assessable. When people engage with the epistemic modality they learn to act, but they are not yet able to become because they are removed from the realities and consequences of their practice.

It is this modality that librarians are most familiar with because it reflects their own discourses about information (as textual) and reflects their own practices with information. However, once information literacy practice moves into the workplace the emphasis changes to focus on the social and corporeal modality.

\section{Social modality}

The social modality is constituted through social interaction and produces tacit knowledge. This type of information is sourced from situated experience of collective participation, practices and reflection on action. The social modality is constituted by the collective histories of people who are engaged in shared practice. It represents the real and ongoing beliefs of participants, consequently information is fluid and ways of knowing are constantly changing. Social information is difficult to articulate through text, but is highly valued by the collective because it reshapes subjectivity towards the construction of collective identity

The negotiation of collective identity occurs through access to information that is rich in its historical, political and social contribution to the maintenance of a community. Participating in shared frameworks of practice and ways of interpreting the world is facilitated within a social site, which gradually draws in new workers from the boundaries of practices and towards the social site. This engagement enables newcomers to connect with the intersubjective space that is controlled by insiders and allows them to form solidarities. Information is disseminated through story telling, narratives about the collective history of the group, and the practices it produces and values. 


\section{Corporeal modality}

The corporeal modality refers to embodied or contingent information drawn and learnt through the body as it practises. Corporeal information is difficult to express in written form and when it is, it is only partially explicit (Blackler, 1995). It is demonstrated through observation of practice or accessed through the tactile, sensory or kinaesthetic activity that is associated with actual performance. Bodies reflect the consciousness of engagement with information. They act as collector of sensory information, a site of knowledge and as a disseminator of physical information. The body in action provides it own narrative that must be observed through its performances. It becomes the intersection between epistemic information, information drawn from actual performance and information drawn from interaction with the community.

\section{From skills to practice}

The idea that information literacy is a set of 'generic skills' is brought into question in workplace research particularly in relation to the transfer of these skills into other contexts. From this perspective, information literacy is often confined to the skills related to information seeking, the search process, and the ethical presentation of information. Central to this is the idea that to become information literate a person needs to recognize information need. However, as Hepworth and Smith (2008) have noted employees do not have to identify an information need, primarily because managers often assign well-defined tasks for them. Similarly, Palmer and Tucker (2004) have noted that while information literacy is seen to be a generic skill and one that underpins all learning, this is not necessarily the case, because of the underlying social conditions that sanction and legitimize information and specific ways accessing information. Bevan (2003) has also argued that while information literacy skills may be validated from a conceptual level as generic skills, this labelling falls down at the concrete or operational level, because it fails to take into account nuances and social practices that are fundamental in the application and practice of information literacy in a context-dependent setting.

By adopting a practice-oriented approach to information literacy, we attempt to understand how the practice is prefigured, and how we come to know the landscape and its practices. Therefore a focus of our exploration should be an emphasis on the activities that afford our engagement with information. These activities can be described as: 
- Information work which is understood as a situated activity and refers to the strategies that are employed not only by members but also the collective strategies of the community to ensure that all members engage with information, sites of knowledge and employ appropriate information skills which reflect the ways of doing things as sanctioned by the community. The way information work is operationalized will depend on the way information and knowledge are understood by the domain. This in turn will influence the type of information related activities that become legitimized.

- Influence work is aimed at ensuring co-participation and mutual understanding about identity, and the maintenance of culture. Characteristic activities of influence work include, mediating, negotiating, interpretation and reinterpretation. Influence work aims at creating alignment between participants who are co-located.

- Information sharing is focussed on negotiation, mutual understanding and shared agreement about ways of acting.

These three activities are enabled by a fourth activity:

- Coupling which draws together the three modalities, and recognizes the affordances and opportunities to engage with the landscape and its signs symbols, artefacts and material objects.

Information literacy as an information practice is way of knowing the information landscape. As a social practice, information literacy reflects the ontology and epistemology of the site through which it is practiced and according to the modalities of information that are valued. Therefore, information literacy emerges through shared, nuanced and embodied understandings about context, through the formulations that prescribe, require or instruct and through the teleoaffective features specific to the site, through which belief and values about information act to influence the collective space of practice.

There is still much work to be done in describing these activities, however (for now) they represent activities that are required in order to develop information literacy practice and to become information literate. 


\section{What is an information literate person?}

Given this practice perspective of information literacy, how can an information literate person be described? An information literate person:

- is informed about the epistemic or social traditions underpinning the foundations of their information practice;

- has developed the practical information skills (technological and otherwise) to perform in their practice and understand the relationship between this experience and performance;

- recognizes their bodily experiences as part of the experience of information gathering which informs practice;

- understands how information is used, disseminated and contested, and uses this information in the performance of workplace practices; and

- understands that information literacy is an ongoing process of reflection about information (Lloyd, 2010b, p.27).

\section{Implications for researchers and library practitioners}

When the focus of information literacy is on how information literacy happens, it can be seen as a complex situated practice that in its development requires us to recognize that the state of being information literate is premised upon knowing, about the information landscape, relating to dimensions of that landscape and doing- developing competencies that enable us to access affordances the landscape.

When information literacy is taught as part of schooling or training or when it is taught in informal settings such as public libraries the emphasis should not only be on the information skill, but on assisting clients to develop an understanding of the ways information literacy practice is shaped and how this shaping influences the sanctioning of skills. There should be more focus on developing critical thinking skills around information production e.g. why is information produced in certain ways, and what influences sanction what can be regarded as information.

There are implications of a practice-oriented approach to information literacy for teachers, librarians and trainers. Firstly as researchers and practitioners we need to engage with our broader communities to understand their information practices and to then reconcile this understanding with our own. By recognizing that the development of an information literate person is not only constituted 
through access to print based information, we are able to account for spoken and unspoken ways of communication that also act as a catalyst for learning, particularly in informal settings. This would enable us to recast information literacy as a collective practice, which in turns opens the way to redevelopment of information literacy programs that take into account the intersubjective nature of information as a collective practice. Secondly, we need to acknowledge that education is preparatory. In this respect we must ask ourselves what is this preparation for? Thirdly, we need to reassess librarian instructional practices - allowing the move away from an 'information skills only' approach, to acknowledge a more holistic way of teaching information literacy. Librarians are educators and more emphasis must be placed on education for this sector.

\section{Conclusion}

Becoming information literate does not just happen because we develop information skills. It happens because others who are co-located and co-participating in the setting stir us into an information landscape. In the process of being stirred into the landscape we connect with a range of information related activities and modalities that enable us to engage with and to know the setting and its practices. Information literacy happens when we engage with signs, symbols and artefacts of our practices. It happens when we engage in the practices that constitute our setting. Information literacy is holistic practice and is the collective possession of the social site, and such it will have specific architectures that structure and reflect ways of knowing within the landscape.

To say that that information literacy is a skills-based literacy is to focus on the individual. This approach denies the socio-cultural discursive, material and historic conditions that determine the ontology and epistemology of a setting, which in turn determines what is accepted as information and what can be considered knowledge. As a practice, information literacy is not only concerned with the operationalization of information skills, but also with understanding why these skills are operationalized. Information literacy is a way of knowing an information landscape and it happens in relation to the conditions that prefigure a social site. 


\section{References}

[1] Barad, K. 1996. Meeting the universe halfway. In J. Nelson \& L. Hankinson (Eds.), Feminism, science, and the philosophy of science (pp.161-194). Dordrecht, Boston: Kluwer Academic Publisher.

[2] Bateson, G. 1972. Steps to an ecology of the mind. San Francisco: Jason Aronson Inc.

[3] Bevan, F. 2003. Developing Information literacy In J. Stevenson (Ed.), Developing Vocational Expertise (pp.110-134). Crows Nest Australia: Allen \& Unwin.

[4] Blackler, F. 1995. Knowledge, Knowledge work and organizations: An overview and interpretation. Organization studies, 16(6): 1021-1046.

[5] Boon, S., Johnston, B., \& Webber, S. 2007. A phenomenographic study of English faculty's conceptions of information literacy. Journal of Documentation, 63(2): 204-228.

[6] Bruce, C. 1997. The seven faces of information literacy. Adelaide: Auslib Press.

[7] Bruce, C. 2000. Information literacy research; Dimensions of the emerging collective consciousness. Australian Academic Research Libraries, 31(2): 91-109.

[8] Bruce, C., Edwards, S., \& Lupton, M. 2007. Six frames for information literacy education: A conceptual framework for interpreting the relationship between theory and practice. In S. Andretta (Ed.), Change and Challenge: Information literacy for the 21st century (pp.37-58). Blackwood South Australia: Auslib Press Pty Ltd.

[9] Bundy, A. 2004. Australian and New Zealand Information Literacy Framework: Principles, standards and practice (2nd ed.): Australian and New Zealand Institute for Information Literacy. Retreived $26^{\text {th }}$ March 2010 from

$<$ http://archive.caul.edu.au/info-literacy/InfoLiteracyFramework.pdf $>$.

[10] Catts, R. 2005. Confirming the Relational Model of Information Literacy. The International Information and Library Review, 37(1): 19-24.

[11] Catts, R., \& Lau, J. 2008. UNESCO. Information for All Programme (IFAP). Towards Information Literacy Indicators. France: UNESCO.

[12] Delors, J. (Chair) 1996. "Learning: the treasure within." Report to Unesco of the International Commission on Education for the Twenty-First Century, Unesco Publishing, Paris.

[13] Doyle, C. 1992. Outcomes measures for information literacy within the National Education goals of 1990. Final report to the national forum on informaiton literacy. Summary of findings ED351 033. Syracuse, N.Y.: Eric Clearinghouse on Information and Technology.

[14] Edwards, S. 2006. Panning for gold: Information literacy and the net lenses model. Adelaide: 
Auslib Press.

[15] Gheradi, S. 2009. Introduction: The critical power of the 'practice lens'. Management Learning, 40(2): 115-128.

[16] Hepworth, M., \& Smith, M. 2008. Workplace Information literacy for administrative staff in higher education. Australian Library Journal, 57(3): 212-236.

[17] Kemmis, S., \& Grootenboer, P. 2008. Situation Praxis in Practice. In S. Kemmis \& T. J. Smith (Eds.), Enabling Praxis (pp.37-62). Rotterdam: Sense Pub.

[18] Limberg, L. 2000. Is there a relationship between information seeking and learning outcomes? In C. Bruce \& Candy.P. (Eds.), Information literacy around the world: Advances in programs and research (pp.193-208). Wagga Wagga: Centre for Information Studies, Charles Sturt University.

[19] Limberg, L., \& Sundin, O. 2006. Teaching information seeking:relating information literacy education to theories of information behaviour. Information Research, 12(1).

[20] Lloyd, A. 2003. Information literacy: the metacompetency of the knowledge economy; an exploratory paper. Journal of Librarianship and Information Science, 35(2): 87-92.

[21] Lloyd, A. 2005. Information literacy; different contexts, different concepts, different truths? Journal of Librarianship and Information Science, 37(2): 82-88.

[22] Lloyd, A. 2006a. Drawing from others; Ways of knowing about information literacy performance. Paper presented at the Lifelong Learning: Parnters, pathways and pedagogies. Keynote and refereed papers from the 4th International Lifelong learning conference, (pp.182-192). Rockhampton: Central Queensland.

[23] Lloyd, A. 2006b. Information literacy landscapes: An emerging picture. Journal of Documentation, 62(5): 570-583.

[24] Lloyd, A. 2007. Learning to put out the red stuff: becoming information literate through discursive practice. Library Quarterly, 77(2): 181-198.

[25] Lloyd, A. 2009. Informing practice: information experiences of ambulance officers in training and on-road practice. Journal of Documentation, 65(3): 396-419.

[26] Lloyd, A. 2010a. Framing information literacy as information practice: site ontology and practice theory. Journal of Documentation, 66(2): 245-258.

[27] Lloyd, A. 2010b. Information literacy landscapes: Information literacy in education, workplace and everyday contexts. Oxford, UK.: Chandos.

[28] Lupton, M. 2004. The learning connection: Information literacy and the student experience. Adelaide: Auslib Press. 
[29] Palmer, S., \& Tucker, B. 2004. Planning, delivery and evaluation of informaiton literacy training for engineering and technology students. Australian Academic Reserach Libraries, March, 13-33.

[30] Palmer, C.L. \& Cragin, M.H. 2008. Scholarly and disciplinary practices. Annual Review of Information Science and Technology, 42: 165-212.

[31] Savolainen, R. 2007. Information behaviour and information practice; Reviewing the 'umberella concepts' of information seeking studies. Library Quarterly, 77(2): 109-132.

[32] Schatzki, T. 1996. Social practices: A Wittgensteinian approach to human activity and the social. Cambridge, UK: Cambridge University Press.

[33] Schatzki, T. 2001. Introduction: The practice turn. In S. T, K. Knorr Cetina \& E. Von Savigny (Eds.), The practice turn in contemporary theory (pp.1-14). London: Routledge.

[34] Schatzki, T. 2002. The site of the social: A philosophical account of the constitution of social life and change. Pennsylvania: Pennsylvania State University Presss.

[35] Schatzki, T. 2006. On Organizations as they happen. Organization Studies, 27, 1863-1873.

[36] Scheeres, H., Solmon, N., Boud, D., \& Rooney, D. 2010. When is it OK to learn at work? The learning work of organisational pratices. Jouranl of Workplace Learning, 22(1/2): 13-26.

[37] Talja, S., \& Lloyd, A. 2010. Integrating theories of learning, literacies and information practices. In A. Lloyd \& S. Talja (Eds.), Practising Information Literacy: Bringing theories of learning, practice and information literacy together (pp.ix-xx). Wagga Wagga, NSW: Centre for Information Studies.

[38] Zurkowski, P. 1974. The information service environment: Relationships and Priorities. National Commission on Libraries and Information Science, Washington DC, ERIC Clearinghouse on Information Resources, ED 100391. 